\title{
Unequal Infrastructure Development (Case Study in Banjarnegara District)
}

\author{
Wiwik Prihatin",a*; Evi Gravitiani2,a \\ ${ }^{1}$ wiwikprihatin.mesp@student.uns.ac.id; ${ }^{2}$ egravitiani2000@gmail.com \\ a Master Of Economics Development Studies, Sebelas Maret University \\ * corresponding author
}

\section{ARTICLE INFO}

Article history

Received 2020-12-21

Revised 2021-03-15

Accepted 2021-03-16

Keywords

Development

Infrastructure

Inequality

\section{ABSTRACT}

This study will discuss the inequality of infrastructure development in terms of various aspects such as road conditions, clean water, solid waste, education, worship, and health. The purpose of this research is to determine the condition of infrastructure development that is not evenly distributed in the Banjarnegara district so that a strategy can be formulated to overcome this problem. The method used is descriptive qualitative using primary data obtained directly through a survey to show how the state of the existing infrastructure and secondary data. The results of this study indicate that inequality in infrastructure development occurs in almost all aspects. Three important and main aspects that must be addressed immediately are related to the construction or repair of road infrastructure because it is the mobility for all community movements to carry out their activities to make it smooth and easy, so that the development of an area is also easy to do. The second is increasing the number of clean water connection service coverage, and the third is handling solid waste management. If this is not done immediately, it will lead to even wider inequality in infrastructure development in the Banjarnegara district considering that infrastructure is also the key to driving economic growth and improving the quality of people's welfare.

This is an open access article under the CC-BY-SA license.

\section{Introduction}

Development is a process of change that is planned through various stages of continuous activities towards a better direction. All aspects of development must be carried out in stages and planned or programmed in every aspect. Development carried out by the government usually only focuses on urban areas rather than rural areas, this will cause a problem, namely inequality of development. According to Williamson (1965), the decline in inequality between regions at an advanced stage is supported by three main factors, one of 
which is the development of infrastructure as a form of alignment of policy makers towards development in less developed areas.

Infrastructure is one of the important aspects for the development of a region. The available infrastructure can improve people's access or mobility to resources. Increasing public access to resources will be followed by increased productivity and efficiency which in turn will also increase economic growth for the region. The existence of infrastructure and all community activities have become an inseparable unit because infrastructure itself has become a basic necessity.

Banjarnegara Regency is one of the areas in Central Java Province where the distribution of infrastructure is still uneven. Infrastructure in Banjarnegara Regency is still centered in Banjarnegara District, which is the center of government. Facilities for education, worship, health, and other basic infrastructure are generally very clearly concentrated in Banjarnegara District. This concentration of infrastructure directly resulted in development gaps that occurred and greatly influenced other aspects of urban development. The more unequal infrastructure in the regional development process will result in the deterioration of other planning aspects such as economic, socio-cultural and aspects related to development policies in Banjarnegara Regency. Based on the background that has been described, the authors are interested in conducting research to provide an analysis of the unequal conditions of infrastructure development in Banjarnegara Regency and discussing related issues which can later formulate a plan or effort that can be made in the development of regional development in Banjarnegara Regency to be better and more evenly distributed.

\section{Method}

The method used in this research is descriptive qualitative research method. According to Denzin and Lincoln (in Moleong, Lexy. J, 2011: 5), qualitative research is research that uses a natural setting, with the intention of interpreting a phenomenon that occurs and is carried out by involving various existing methods. This qualitative research is conducted based on phenomena originating from the real world (practice), as well as theoretical gaps and research gaps (Indrawan. R and Yaniawati. RP, 2016: 68). The type of data used is primary data which is obtained directly through primary surveys to show how the state of the existing infrastructure is and secondary data comes from literature studies or a review of various literature related to the problem under study. 


\section{Location and Time of Research}

The location of the research was carried out in Banjarnegara Regency, which is located between 7ํ12 '- 7ㅇ31' South Latitude and 10929 '- 10945'50 "East Longitude which has an area of $1,070 \mathrm{Km}^{2}$, there are 20 sub-districts consisting of 266 villages and 12 subdistricts. The research was carried out for one month, namely November-December 2020. Geographically, the Banjarnegara Regency is located in the mountainous route of the central part of Central Java Province which stretches from west to east. The administrative boundaries of Banjarnegara Regency are as follows:

North : : Batang Regency and Pekalongan Regency

East : Wonosobo Regency

South side : : Kebumen Regency

West Side : : Banyumas Regency and Purbalingga Regency

Discussion

Etymologically, facilities and infrastructure have differences, but both have a very important relationship as a means of supporting the success of a development process carried out. In other words, a process of development activities that will be carried out will not be able to achieve the expected results in accordance with the plan if the facilities and infrastructure are not available and are not evenly distributed. Ideally, the role of infrastructure will greatly affect the socio-economic environment of the community. The results of the analysis of the infrastructure condition analysis inBanjarnegara Regency can be explained from the condition of roads, clean water, solid waste, education, worship, health, as well as the formulation of strategies for various existing problems.

\section{Road Facility Conditions}

According to Law no. 13 of 1980 regarding the road, the road is a land transportation infrastructure in any form which includes all parts of the road including complementary buildings and equipment intended for traffic. Road complementary buildings are buildings that cannot be separated from roads such as bridges, over pass, under pass and others. Meanwhile, road equipment includes road signs and markings, traffic safety fences, damija fences and etc.

The road network system in Banjarnegara Regency is traversed by the main route that connects important areas in Central Java Province. Based on the type of surface, the roads in Banjarnegara Regency are divided into three parts, namely dirt roads, asphalt roads, gravel or stone roads. Especially for asphalt roads consisting of district roads, provincial roads and national roads. The following is a picture of a road in Banjarnegara Regency. 


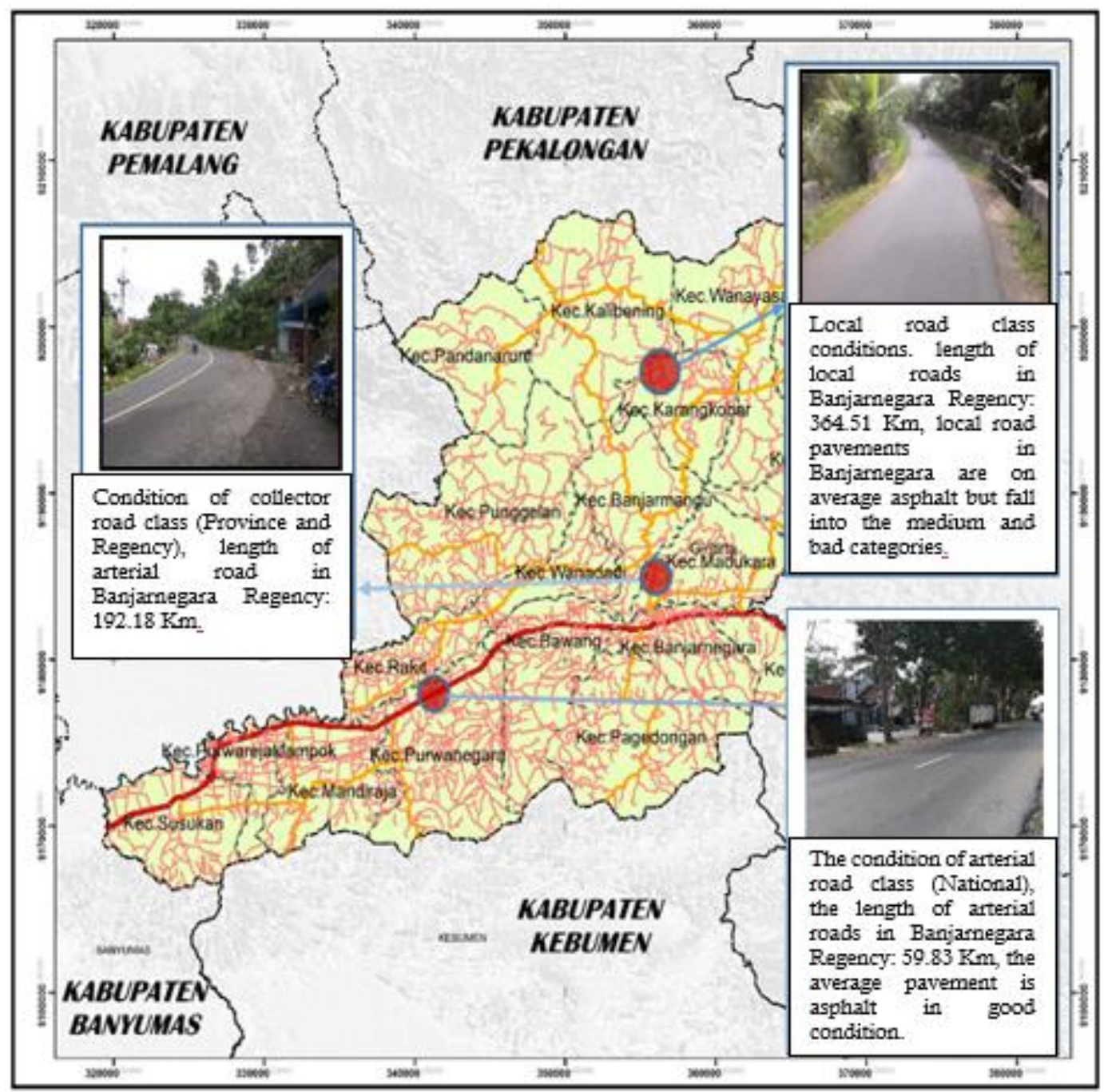

Source: Analysis Results (2020)

Figure 1. Road Network Condition in Banjarnegara Regency

There are many road conditions that do not meet the rules such as in terms of arrangement and there is no detailed planning of environmental management, especially road parks. It is usually difficult to develop a road network in the district of Banjarnegara, especially in sub-districts that have forest areas managed by Perhutani. This causes accessibility in the sub-district to be very limited due to the lack of access to the road network. For example, Pagedongan, Wanayasa, Pandanarum and Kalibening sub-districts, which have production forest areas managed by Perhutani. In these sub-districts, apart from the inadequate topography of the area for road network expansion, a license from Perhutani is also required in connection with the expansion of the transportation network through the production forest area. 


\section{Clean Water Infrastructure Conditions}

Clean water infrastructure is one type of infrastructure that has an important role in supporting the fulfillment of community needs for clean water which must remain available and sustainable, so that it is able to support life and the implementation of development in the present and in the future. Clean water infrastructure in Banjarnegara Regency is served by PDAM, wells and springs.

Table 1. Piped Clean Water Infrastructure (PDAM) and Non-Piped

\begin{tabular}{lccc}
\hline Village / Sub-district & \multicolumn{3}{c}{ Source of Clean Water (*. in SR) } \\
\cline { 2 - 4 } & PDAM (Sr) & Well & Water Springs \\
\hline $\begin{array}{l}\text { Village / Ex. All } \\
\text { Banjarnegara Regency }\end{array}$ & 212 & 50,236 & 4368 \\
\hline
\end{tabular}

Source:Data Collection Results and Data from Dispermades of Banjarnegara Regency (2017) *) Description: $S R=$ household connection.

Based on the table above, the population in Banjarnegara Regency in almost all areas included in the rural category still rely on springs as the main source of clean water to meet their daily needs for clean water. The wells with a total of 50,236 are scattered in almost all villages / kelurahan. The sub-district with the highest number of clean water sources coming from springs is Pejawaran District, especially in Karangsari Village, with 816 wells, while the PDAM service is still limited to the city center and its surroundings. The limited supply of clean water by PDAM can cause difficulties for residents who are far from the main roads.

\section{Solid Waste Infrastructure Conditions}

According to PP. 81 of 2012 concerning Management of Household Waste and Waste Similar to Household Waste, waste management is a systematic, comprehensive, and sustainable activity which includes waste reduction and handling. In terms of solid waste management in Banjarnegara Regency, it is handled by the Environment Agency (DLH). Where is the waste sorting system carried out which will later be brought to the Final Processing Site (TPA). Meanwhile, rural communities still dispose of or manage waste by burning it or burying it in the house yard. The level of public awareness in terms of solid waste management has not been maximal.

Based on the results of a rural survey in Banjarnegara Regency, only one sub-district has a TPA (Final Processing Place), namely Bawang District, Winong Village. As for TPS (Temporary Shelters), it is almost evenly distributed in eleven sub-districts. The highest number of TPS is in Banjarnegara Subdistrict with a total of 24 TPS spread across all sub- 
districts / villages in Banjarnegara District. The least number of TPS is in Banjarmangu District. The condition of solid waste infrastructure can be seen at Figure 2.

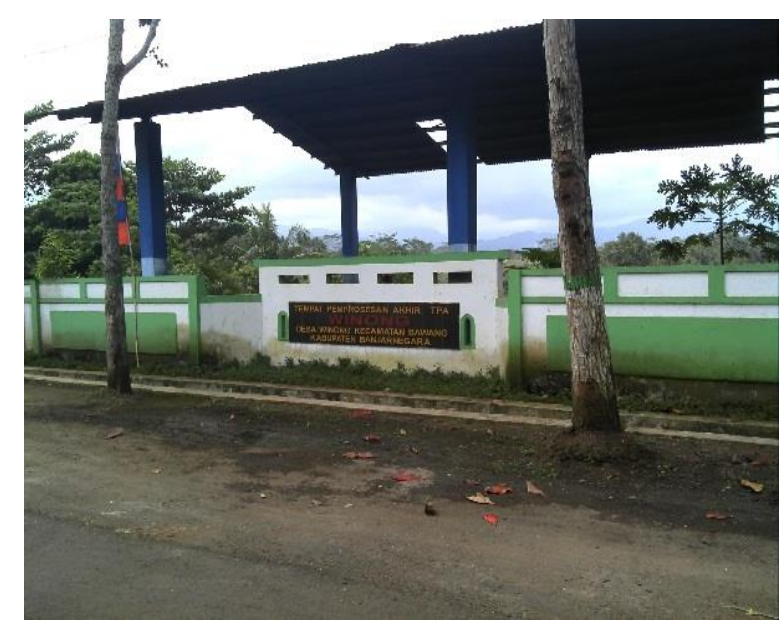

Source: Analysis Results (2020)

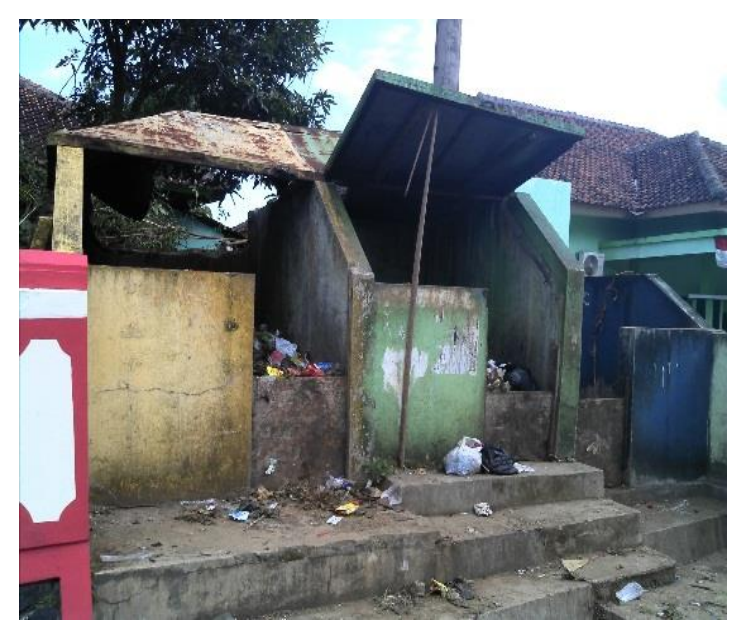

Figure 2. TPS and TPA conditions in Banjarnegara Regency

\section{Conditions of Educational Facilities}

Educational facilities are the means provided to meet the needs of society for education. Educational facilities have the lowest levels of Paud / Kindergarten, SD, SMP, SMA, Higher Education. Banjarnegara Regency has complete educational facilities for all levels of education. Divided and scattered throughout the District, both public and private. The need for buildings for educational facilities and other supporting facilities depends on the level of education. Efforts are made to provide educational facilities to support the level of education of an area and equal distribution of education and the educational infrastructure provided is the availability of a park or educational RTH, a field for ceremonial activities.

Educational institutions at Banjarnegara Regency is managed by the Government and the private sector. Institutions managed by the government or commonly called public schools consist of 4 units of Kindergarten, 617 units of SD / equivalent, 75 units of SMP / equivalent, and 8 units of SMA / equivalent. Meanwhile, educational institutions managed by the private sector consist of 303 TK units, 13 SD / equivalent units, 23 SMP / equivalent units, and 5 SMA / equivalent units. 


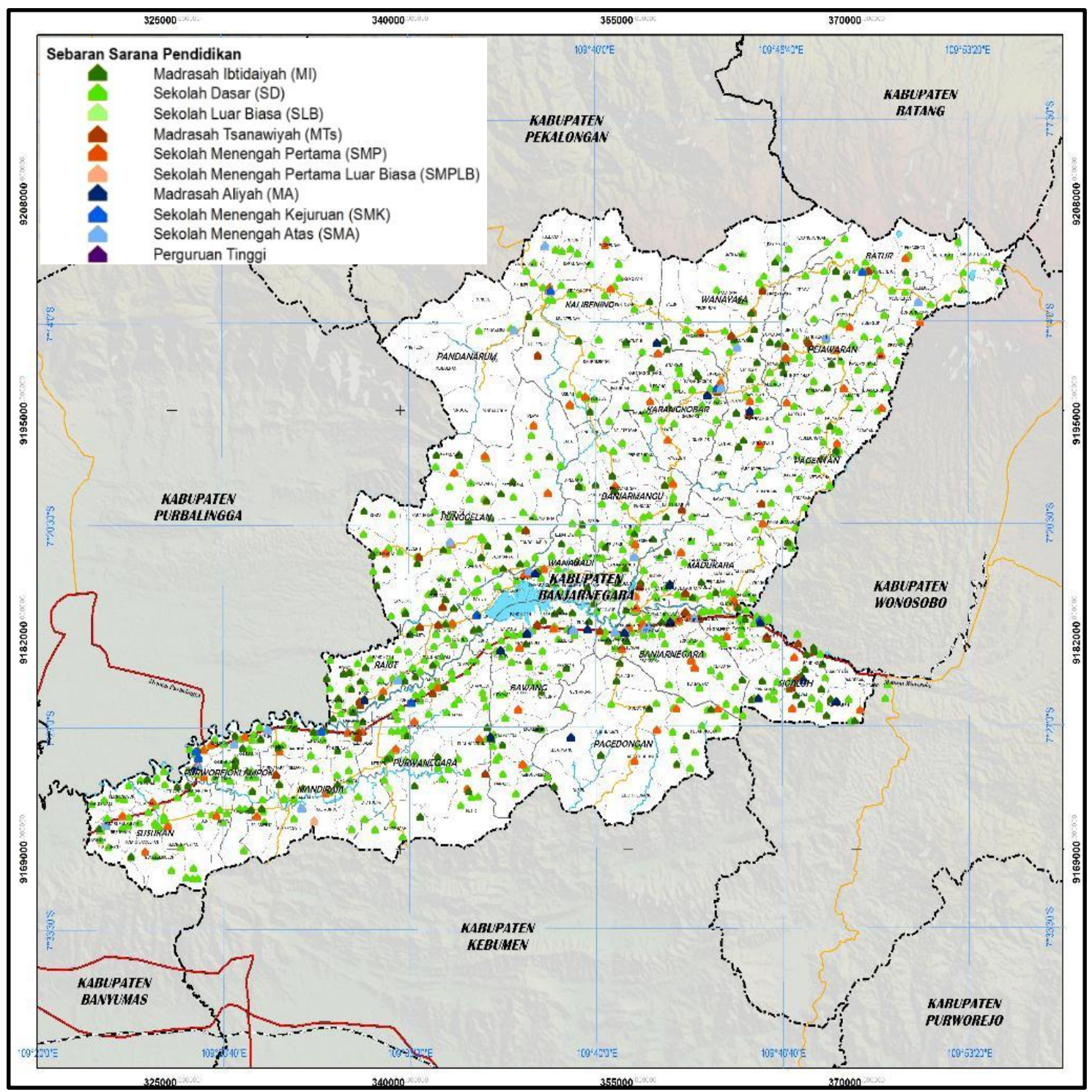

Source: Analysis Results (2020)

Figure 3. Distribution of Educational Facilities in Banjarnegara District

\section{Conditions of Worship Facilities}

Worship facilities are public facilities and function as places of worship for the local community. Usually, the existence of places of worship is in accordance with the population of a certain religion, for example in an area the majority of the population is Islam, therefore the number of mosques will be far more than the number of other places of worship. In Banjarnegara Regency, the majority of the population is Muslim, therefore the number of mosques and prayer rooms is far more than others. In Banjarnegara Regency, there are four types of worship facilities, namely mosques / prayer rooms, churches, monasteries and temples. The following is a picture of the distribution of religious facilities in Banjarnegara Regency. 


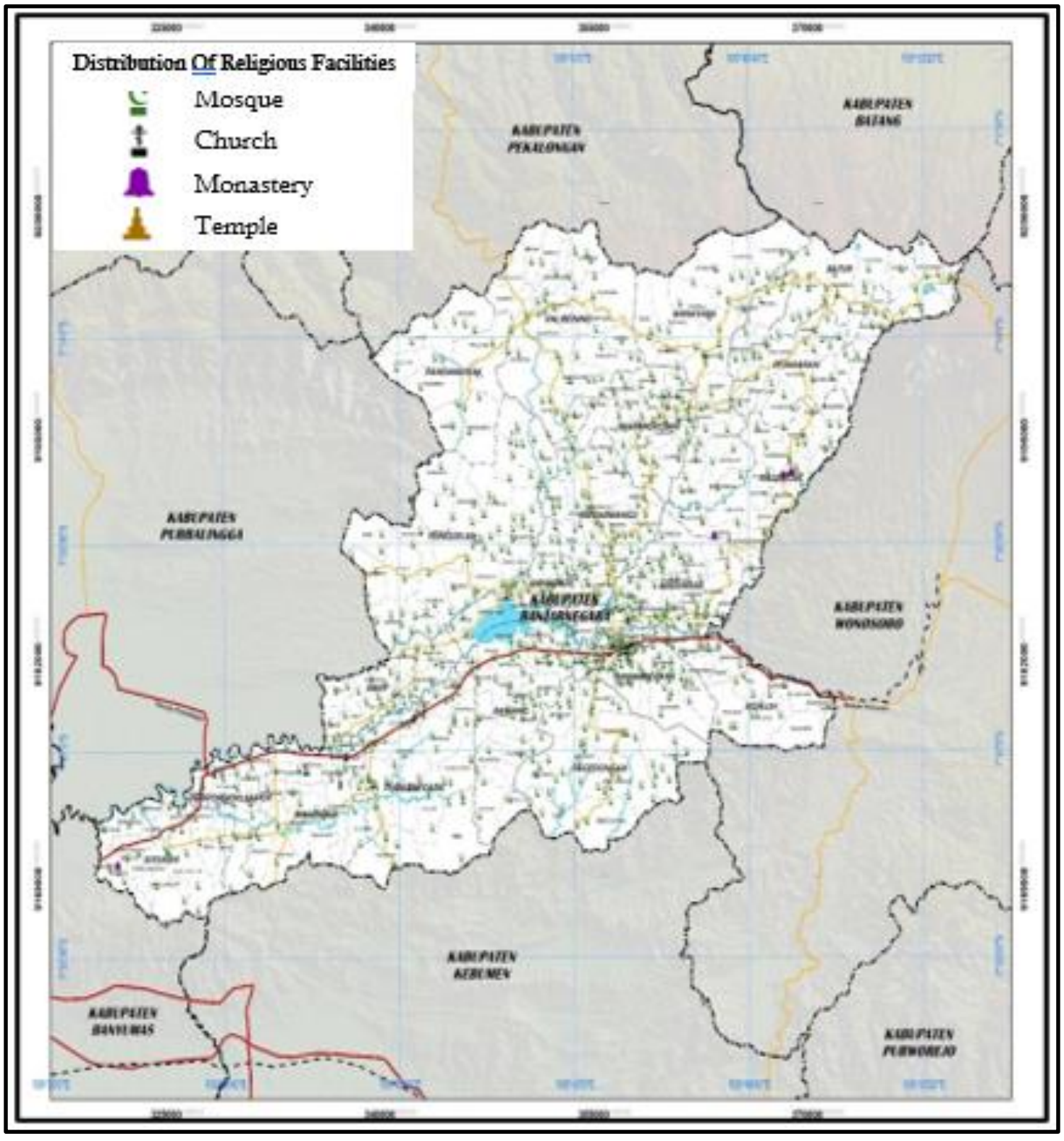

Source: Analysis Results (2020)

Figure 4. Distribution of Worship Facilities in Banjarnegara Regency

For religious facilities, Banjanegara Regency itself has 2532 units of mosques, 43 units of churches, 1 unit of temple and 7 units of Vihara. These religious facilities in the form of mosques have been scattered throughout the districts, but for other worship facilities only in certain districts. The condition of the buildings for worship facilities can be said to be good because they are well maintained and are always visited by people who want to worship.

\section{Condition of Health Facilities}

Provision of health facilities is a basic need in an effort to improve the health status of the community and is one of the main concerns of development in the health sector with the 
aim that the community can enjoy health services. Health facilities in Banjarnegara Regency include a number of hospitals, health centers, clinics and pharmacies. Banjarnegara District is the most complete sub-district in providing this facility.

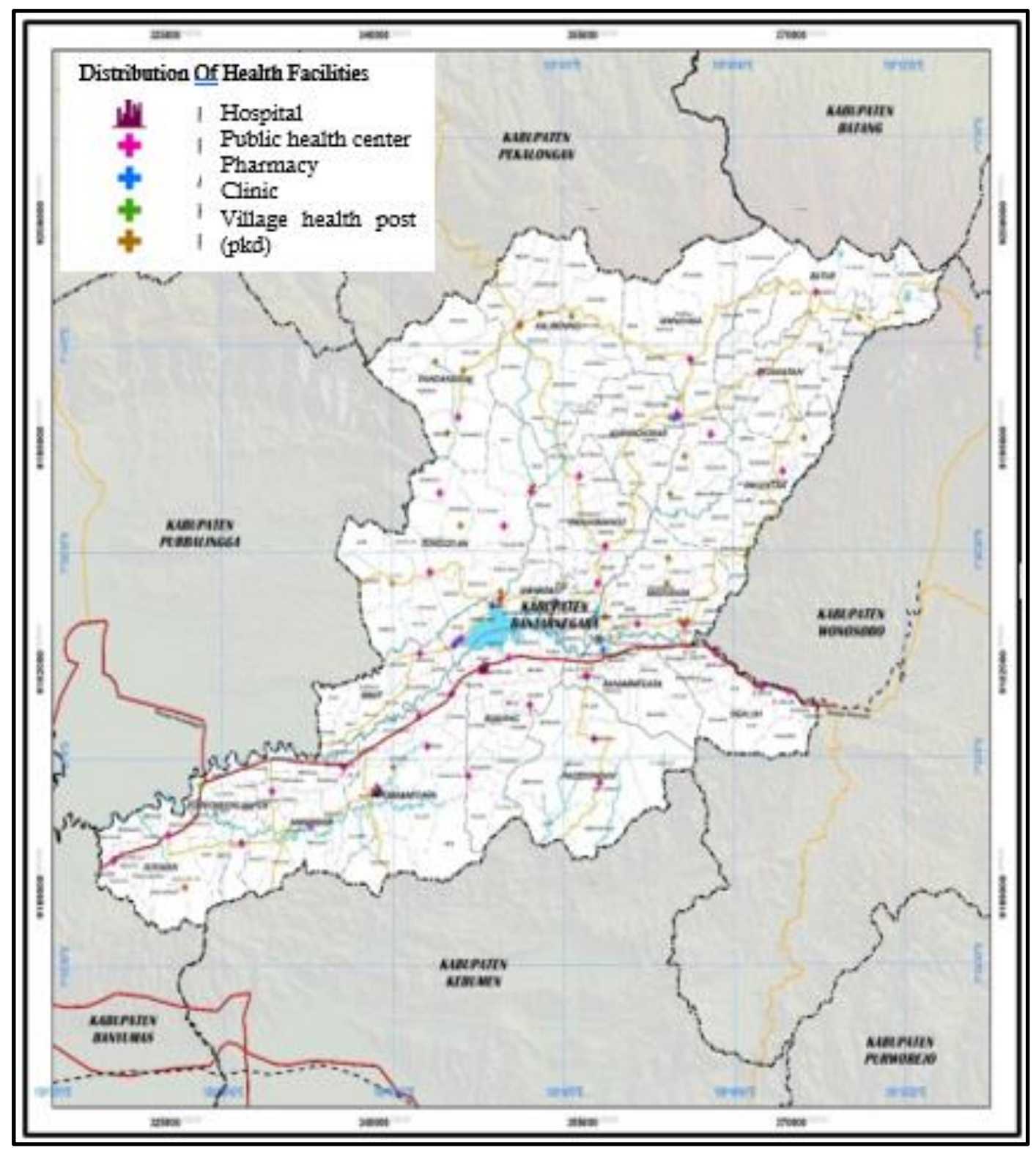

Source: Analysis Results (2020)

Figure 5. Distribution of Health Facilities in Banjarnegara District

There are 3 hospital units, namely in Banjarnegara, Bawang and Purwareja Klampok Districts. Puskesmas are spread evenly in every sub-district in Banjarnegara Regency, on average each District has more than one to 2 Puskesmas (inpatient Puskesmas / Auxiliary Puskesmas). There are 14 clinics in Banjarnegara Regency, which are spread out in Banjarnegara District (6 units); Onions (3 units); Mandiraja 1 and several other kecamatan have an average of 1 clinic. There are no pharmacies in Banjarnegara district in all subdistricts, but only in certain sub-districts. The largest number of pharmacies is in 
Banjarnegara District with 13 units. Meanwhile, in Pandanarum Subdistrict, Pej Offer, Pagentan does not have a pharmacy at all.

\section{Infrastructure Repair Strategy in Banjarnegara Regency}

The potential and completeness of the existing infrastructure in Banjarnegara Regency after being analyzed and observed still have many obstacles and are not sufficient for the standard of a regional area. It must again need the care of the surrounding community and assistance from the government to fix the problems that still arise and occur in relation to existing facilities and infrastructure. So that it will cause no overlap between the community and there will be no disputes due to the lack of availability of facilities and infrastructure. So the plans or efforts that can be taken to overcome problems and improve infrastructure in the Banjarnegara Regency from the results of the analysis that have been carried out are: 1. Improve the quality of the road network with a good paving system; Development and repair of pedestrian paths (pedestrians) on main roads in the Banjarnegara Regency.

2. Develop a clean water infrastructure system withincreasing the coverage of clean water connection services to unserved houses and constructing supporting buildings for clean water networks.

3. Waste handling by adding TPA in the Banjarnegara Regency area; TPS procurement for markets, offices, shops, irregular settlements and so on; Carry out a 3R waste management program.

\section{Infrastructure Development Issues in Banjarnegara Regency}

As previously mentioned, the issues discussed in Kabupaten Banjarnegara are related to the unequal development of the physical or infrastructure aspects. Infrastructure including facilities and infrastructure in Banjarnegara Regency is generally still not evenly distributed both in quantity and quality. Basically, the completeness or availability of facilities in an area greatly affects the attractiveness of migration and physical development in an area. So it is a natural thing to happen when Banjarnegara District and several surrounding sub-districts begin to show clearer urban characteristics compared to other areas which are still very visible characterized as rural areas.

Of the various types of facilities and infrastructure, roads are the easiest aspect to observe for comparing the quality of infrastructure in Banjarnegara Regency. The roads in Banjarnegara Regency, if based on the status of the existing roads, can be divided into neighborhood roads, village roads, district roads, provincial roads, and national roads. In general, roads with the status of national and provincial roads are very good with concrete pavements. 


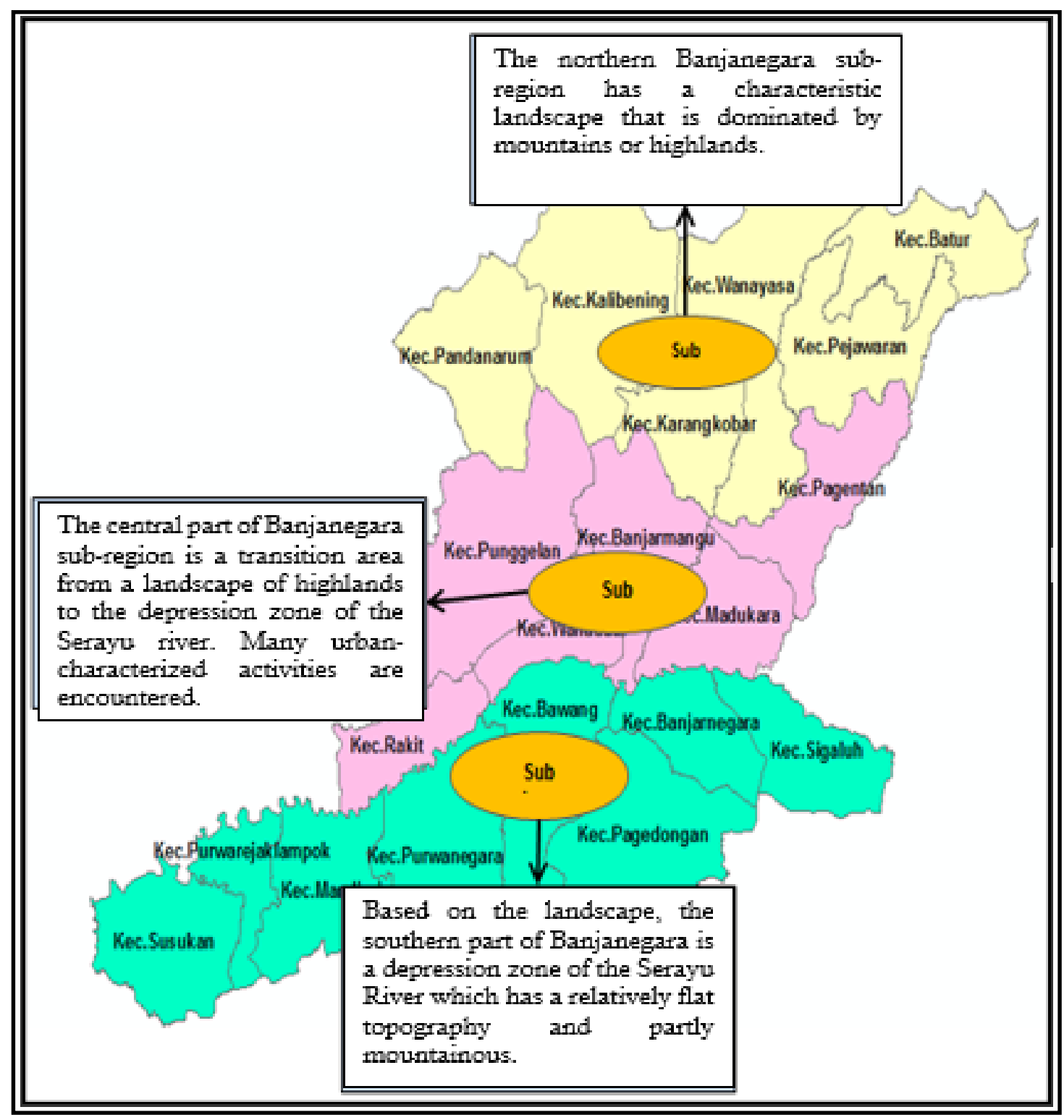

Source: BAPPEDA Banjarnegara Regency (2017)

Figure 6. Division of Sub-Regions in Banjarnegara Regency

In contrast to the provincial and national roads which are of good quality, quite a number of district and village roads in Kabupaten Banjarnegara are still not very feasible. Some roads already have pavement in the form of asphalt and / or concrete and there is no damage. However, some of them were damaged, either just having holes in them or even experiencing serious damage because the asphalt as the main pavement had been destroyed.

The unequal infrastructure development in Banjarnegara Regency is inseparable from the variety of landscape and topographic conditions in Banjarnegara Regency. This also results in inequality in development, physically, socially, and economically. The landscape 
condition is divided into 3 sub-regions, namely the northern, central and southern Banjarnegara sub-regions.

\section{REFERENSI}

Badan Perencanaan Pembangunan Daerah (BAPPEDA) Kabupaten Banjarnegara. (2017). “Kerangka Acuan Kerja Penyusunan Rencana Pengembangan Wilayah Perdesaan Kabupaten Banjarnegara.

Badan Pusat Statistik Kabupaten Banjarnegara. (2020). Kabupaten Banjarnegara Dalam Angka 2019.

Cahyadin, M dan Pamrihnan, A (2016). “Analisis Ketimpangan Pendapatan Dan Identifikasi Sektor Basis Antar Kecamatan Di Kabupaten Wonogiri Tahun 2010-2014". Jurnal Ilmu Ekonomi Pembangunan Universitas Sebelas Maret, Vol. 16, No.2, hlm.75.

Faizah, Ajeng. (2018) 'Blue Economy: Keseimbangan Perspektif Ekonomi dan Lingkungan.

Iskandar, D dan Hapsari, A (2018). “Analisis Faktor-Faktor Yang Mempengaruhi Pertumbuhan Ekonomi Provinsi Jawa Tengah Periode 2010-2014". Jurnal Ilmu Ekonomi Pembangunan Universitas Sebelas Maret, Vol. 18, No.1, hlm.71.

Niken Pratiwi, Dwi Budi, Khusnul Ashar (2018). "Analisis Implementasi Pembangunan Berkelanjutan Di Jawa Timur". Jurnal Ilmu Ekonomi Pembangunan Universitas Sebelas Maret, Vol. 18, No.1, hlm.2.

Peraturan Daerah Kabupaten Banjarnegara Nomor 11 tahun 2011 tentang RTRW Kabupaten Banjarnegara Tahun 2011 - 2031.

Tri Darmawanto, A dan Zaini, M (2015). “Implementasi Pembangunan Berkelanjutan Berwawasan Lingkungan Studi Pada Kelurahan Lempake Kecamatan Samarinda Utara Kota Samarinda". Jurnal Ilmu Ekonomi Pembangunan Universitas Sebelas Maret, Vol. 15, No.2, hlm.28-29. 